Article

\title{
Fermentative Production of Lasiodiplodan by Lasiodiplodia theobromae CCT3966 from Pretreated Sugarcane Straw
}

\author{
Peyman Abdeshahian ${ }^{1, *}$, Jesús Jiménez Ascencio ${ }^{1}$, Rafael R. Philippini ${ }^{1}{ }^{\circledR}$, Felipe Antonio Fernandes Antunes ${ }^{1}$, \\ Avinash P. Ingle ${ }^{2}$, Mojgan Abdeshahian ${ }^{3}$, Júlio César dos Santos ${ }^{1}$ and Silvio Silvério da Silva ${ }^{1}$ \\ 1 Department of Biotechnology, Engineering School of Lorena, University of São Paulo, \\ São Paulo 12602-810, Brazil; ascencio.jejias@gmail.com (J.J.A.); philippinir@gmail.com (R.R.P.); \\ felipeantunes22@gmail.com (F.A.F.A.); jsant200@usp.br (J.C.d.S.); silviosilverio@usp.br (S.S.d.S.) \\ 2 Biotechnology Centre, Department of Agricultural Botany, Panjabrao Deshmukh Krishi Vidyapeeth, \\ Akola 444104, India; ingleavinash14@gmail.com \\ 3 Department of Agriculture Science, Payame Noor University (PNU), Tehran 19395-4697, Iran; \\ moshahian@gmail.com \\ * Correspondence: peyman_137@yahoo.com
}

\section{check for}

updates

Citation: Abdeshahian, P.; Ascencio, J.J.; Philippini, R.R.; Antunes, F.A.F.; Ingle, A.P.; Abdeshahian, M.; Santos, J.C.d.; Silva, S.S.d. Fermentative Production of Lasiodiplodan by Lasiodiplodia theobromae CCT3966 from Pretreated Sugarcane Straw. Sustainability 2021, 13, 9697. https://doi.org/10.3390/ su13179697

Academic Editor: Matthew Jones

Received: 22 June 2021

Accepted: 23 August 2021

Published: 29 August 2021

Publisher's Note: MDPI stays neutral with regard to jurisdictional claims in published maps and institutional affiliations.

Copyright: (c) 2021 by the authors. Licensee MDPI, Basel, Switzerland. This article is an open access article distributed under the terms and conditions of the Creative Commons Attribution (CC BY) license (https:/ / creativecommons.org/licenses/by/ $4.0 /)$.
Abstract: Lasiodiplodan is a $\beta$-glucan polymer with different interesting characteristics, including therapeutic properties. It is an extracellular product, which is produced by the filamentous fungus Lasiodiplodia theobromae, using glucose as a substrate. In the present work, the production of lasiodiplodan was studied by the utilization of sugarcane straw as a low-cost carbon source. Glucose-rich sugarcane straw hydrolysate was obtained by a sequential pretreatment with dilute nitric acid $(1 \% v / v)$ and sodium hydroxide $(1 \% w / v)$, followed by enzymatic hydrolysis. The fermentation process was conducted by the cultivation of the strain Lasiodiplodia theobromae CCT3966 in sugarcane straw hydrolysate in a shake flask at $28^{\circ} \mathrm{C}$ for $114 \mathrm{~h}$. It was found that hydrolysate obtained after enzymatic hydrolysis contained $47.10 \mathrm{gL}^{-1}$ of glucose. Fermentation experiments of lasiodiplodan synthesis showed that the peak yield and productivity of $0.054 \mathrm{gg}^{-1}$ glucose consumed and $0.016 \mathrm{gL}^{-1} \mathrm{~h}^{-1}$, respectively, were obtained at $72 \mathrm{~h}$ fermentation time. Fungal growth, glucose consumption, and lasiodiplodan production from sugarcane straw hydrolysate presented a similar pattern to kinetic models. The study on the chemical structure of lasiodiplodan produced showed it had a $\beta$-glucan construction. The current study revealed that sugarcane straw is a promising substrate for the production of lasiodiplodan.

Keywords: lasiodiplodan; sugarcane straw; Lasiodiplodia theobromae CCT3966; fermentation process

\section{Introduction}

$\beta$-glucans are polysaccharide-based polymers, which have promising applications in medicine and pharmaceutical sectors because they have been found to possess potential antimicrobial and anticancer properties. In addition, these polymers play a crucial role in the improvement of the human immune system and decrease of blood cholesterol and also helps in wound healing. Moreover, $\beta$-glucans can be effectively used in the cosmetics and food industry as fat substitutes, emulsifiers, and food fibers [1-3]. Many microorganisms such as fungi and bacteria were reported to have the ability of $\beta$-glucan synthesis using carbon sources. Among them, the filamentous fungus Lasiodiplodia theobromae has received a growing interest by researchers for the biosynthesis of an extracellular $\beta$-glucan polymer, namely lasiodiplodan, since this fungus has a high potential for industrial production level $[1,4]$. In this regard, the tremendous biological characteristics of lasiodiplodan such as anti-proliferative effect on breast cancer cells, hypoglycemic function, and antioxidant activities have made it an attractive biopolymer for commercial applications [5,6]. Generally, the production costs of the fermentative products highly depend on the fermentation substrates, mainly carbon source, as the use of raw materials such as lignocellulosic biomass and agro-industrial residues decrease the manufacturing costs [7]. 
Current efforts for microbial synthesis of lasiodiplodan are based on the utilization of commercial sugars, particularly glucose [4,5,8-10]. These sugars are mostly obtained from unsustainable carbon sources such as food-derived carbohydrates, which strongly compete with food chains [11,12]. Furthermore, the production process will be costly where large-scale synthesis of glucan is targeted. Hence, production of lasiodiplodan from commercial sugars is not cost-efficient. In order to attain process economics and successful industrialization of lasiodiplodan production, the exploitation of abundant, renewable, and low-cost natural bioresources enhances economically feasible production of lasiodiplodan [13]. Considering these facts, there is a rising trend in the utilization of waste carbon sources for the production of biochemicals. Lignocellulosic feedstocks are the most versatile and viable carbon sources, which could provide fermentable sugars for the biological synthesis of chemicals. Moreover, these raw materials are promising carbon sources and economically competitive ones as compared with food-based carbon sources [14,15]. However, current knowledge about lasiodiplodan synthesis from lignocellulosic biomass is rudimentary and very limited research has been performed in this regard $[13,16]$.

Sugarcane is known as one of the most abundant industrial crops in Brazil. Harvesting sugarcane leads to the generation of a lignocellulosic residue, namely sugarcane straw (tops and dry leaves of sugarcane plant) with an amount of 10-30 mega gram per hectare $\left(\mathrm{Mg} \mathrm{ha}{ }^{-1}\right)$, which is left on the land after harvesting [17,18]. In this regard, 14\% dry weight of the sugarcane plant forms sugarcane straw in sugarcane processing chains [19]. Considering the large production of sugarcane in Brazil (642.72 million metric tons of sugarcane in Brazil's marketing year for the duration March 2019-April 2020), a high quantity of sugarcane straw is produced [20]. A part of sugarcane straw is left on the ground to make soil fertile [21]. The rest of the sugarcane straw can be utilized as an energy source or as a lignocellulosic feedstock for the production of biochemicals and value-added products [22]. The lignocellulosic structure of sugarcane straw is composed of a high content of cellulose ranging from $37 \%$ to $44.5 \%[23,24]$. The high amount of cellulose in sugarcane straw represents a potential and low-cost carbon source to obtain fermentable sugars, which could further be utilized for the production of biochemicals such as lasiodiplodan.

In order to access cellulosic fraction for effective hydrolysis by cellulolytic enzymes, a pretreatment step is often imperative to partly break the recalcitrant structure of the lignocellulose and to allow the removal of hemicellulose and lignin constituents, which in turn leads to the enhancement of cellulose hydrolysis [25-30]. In this context, several pretreatment methods have already been applied to fractionate the lignocellulosic components of biomass [31]. Among them, dilute acid treatment has potential for the dissociation of hemicellulose component, which could be utilized efficiently in industrial sectors. Acid pretreatment followed by alkaline pretreatment for delignification of biomass has commonly been used to obtain a high amount of cellulose content [25,32-34]. Different acids such as sulfuric $\left(\mathrm{H}_{2} \mathrm{SO}_{4}\right)$, hydrochloric $(\mathrm{HCl})$, nitric acid $\left(\mathrm{HNO}_{3}\right)$, and phosphoric acid $\left(\mathrm{H}_{3} \mathrm{PO}_{4}\right)$ have been used for the pretreatment of lignocellulosic biomass [33]. Among these, $\mathrm{HNO}_{3}$ was reported to have the less corrosive effect on equipment, and has been faster and more effective for fractionating lignocellulose structure [35].

The study fulfilled by Abdeshahian et al. [36] showed that an untreated sample of sugarcane straw was composed of $41.25 \%$ cellulose, $35.17 \%$ hemicellulose, $17.25 \%$ lignin, and $2.81 \%$ ash. This indicates that sugarcane straw could be regarded as low-cost lignocellulosic biomass to obtain glucose, which can be further used for the production of glucan biopolymer through microbial fermentation process.

Therefore, the aim of this study was to investigate the feasibility of lasiodiplodan production from the sugarcane straw, which was subjected to a sequential pretreatment by diluted nitric acid $\left(\mathrm{HNO}_{3} 1 \% v / v\right)$ and $\mathrm{NaOH}(1 \% w / v)$. In this study, the fungal strain L. theobromae CCT3966 was cultivated on the glucose obtained from enzymatic saccharification of pretreated sugarcane straw to synthesize lasiodiplodan. Moreover, a kinetic model for the production of lasiodiplodan by the fungal strain in the fermentation 
medium was studied. The chemical structure of lasiodiplodan produced was studied using Fourier Transform Infrared Spectroscopy (FT-IR) and X-ray diffractometry.

\section{Materials and Methods}

\subsection{Raw Material}

Sugarcane straw was obtained from Ipiranga Agroindustrial in Descalvado, São Paulo, Brazil. Sugarcane straw collected with moisture content of less than $10 \%$ was then milled using a laboratory knife mill unit. The milled sugarcane straw was transferred in a plastic bag and stored at the temperature of $4{ }^{\circ} \mathrm{C}$ prior to its use for experiments.

\subsection{Microorganism}

The filamentous fungal strain Lasiodiplodia theobromae CCT3966 was procured from Fundação André Tosello Pesquisa e Tecnologia (Campinas, São Paulo, Brazil). The isolate was maintained on the yeast malt agar (Sigma-Aldrich, São Paulo, Brazil) with the chemical composition of $\left(\mathrm{gL}^{-1}\right)$ : dextrose, 10; yeast extract, 3; malt extract, 3; peptone, 5, and agar, 20 , with a $\mathrm{pH}$ value of 6.2 at $30^{\circ} \mathrm{C}$. The fungal inoculum was prepared by the cultivation of the strain on yeast malt agar slant in $500 \mathrm{~mL}$ flasks at $30^{\circ} \mathrm{C}$. After growing fungal cells, a defined volume of sterile distilled water containing $0.1 \%$ Tween 80 was added to the flask, and mixed well. A fungal suspension was prepared for inoculation of the production culture.

\subsection{Pretreatment of Sugarcane Straw}

Initially, the raw sugarcane straw was subjected to the pretreatment by the acid solution to remove hemicellulose fraction. For acid pretreatment, dilute nitric acid $\left(\mathrm{HNO}_{3}\right.$ $1 \% v / v)\left(\right.$ Labsynth $^{\circledR}$, São Paulo, Brazil) was used with a solid to liquid ratio of 1:10. In this way, $20 \mathrm{~g}$ raw sugarcane straw was placed in $500 \mathrm{~mL}$ Erlenmeyer flask and $200 \mathrm{~mL}$ of dilute $\mathrm{HNO}_{3}$ was added, followed by vigorous mixing. The flask was then transferred into an autoclave and heated at $121^{\circ} \mathrm{C}$ for $60 \mathrm{~min}$ [37]. The solid part was then collected, washed with water $(\mathrm{pH} 7)$ and dried until the moisture content reached less than $10 \%$.

To remove the lignin fraction from biomass, the acid pretreated sugarcane straw was subjected to alkaline pretreatment. It was conducted by mixing cellulignin portion with a $\mathrm{NaOH}(1 \% w / v)\left(\right.$ Labsynth $^{\circledR}$, São Paulo, Brazil) solution in a solid to liquid ratio of 1:10. For this, $200 \mathrm{~mL} \mathrm{NaOH}$ solution was transferred to a $500 \mathrm{~mL}$ Erlenmeyer flask containing $20 \mathrm{~g}$ of acid pretreated sugarcane straw and mixed well. The mixture was heated at $121^{\circ} \mathrm{C}$ for $60 \mathrm{~min}$ using an autoclave [38]. Later, the solid fraction was separated from the liquid part. The solid part was washed with water to remove lignin adhered to biomass and neutralize delignified sugarcane straw. The pretreated sugarcane straw was dried until the moisture content reached less than $10 \%$.

\subsection{Enzymatic Hydrolysis}

Delignified sugarcane straw was subjected to enzymatic saccharification for conversion of cellulose fraction to glucose. The enzymatic hydrolysis of the pretreated sugarcane straw was performed using a commercial enzyme preparation, namely Cellic ${ }^{\circledR}$ CTec2 (Sigma-Aldrich, Brazil Ltd., São Paulo, Brazil) in 125 mL Erlenmeyer flasks. The hydrolysis assay was conducted at a solid loading of $7.5 \%(w / v)$ using $50 \mathrm{mM}$ sodium citrate buffer (pH 5.0) in a total volume of $40 \mathrm{~mL}$, so that the enzyme loading of $15 \mathrm{FPU}$ (filter paper units) per gram of dry biomass was applied for $72 \mathrm{~h}$ at $50^{\circ} \mathrm{C}$. The mixture was then centrifuged at $2860 \times \mathrm{g}$ for $10 \mathrm{~min}$. The obtained hydrolysate was stored at $-18{ }^{\circ} \mathrm{C}$. The amount of glucose in hydrolysate was measured and the cellulose to glucose conversion $\left(\mathrm{X}_{\mathrm{C}-\mathrm{G}}\right)$ was calculated using Equation (1):

$$
\mathrm{X}_{\mathrm{C}-\mathrm{G}}=\frac{\mathrm{C}_{\mathrm{G}}}{\mathrm{C}_{\mathrm{B}} \times \mathrm{f} \times 1.11} \times 100
$$


where $\mathrm{X}_{\mathrm{C}-\mathrm{G}}$ shows the glucose conversion value $(\%), \mathrm{C}_{\mathrm{G}}\left(\mathrm{gL}^{-1}\right)$ denotes the concentration of glucose released at the time of sampling, $\mathrm{C}_{\mathrm{B}}\left(\mathrm{gL}^{-1}\right)$ represents the concentration of delignified sugarcane straw used in the flask before the beginning of enzymatic hydrolysis, $\mathrm{f}$ indicates the content of cellulose in the dry delignified sugarcane straw, and 1.11 denotes cellulose to glucose conversion coefficient [39].

\subsection{Production of Lasiodiplodan}

Lasiodiplodan production was conducted in a $125 \mathrm{~mL}$-Erlenmeyer flask containing sugarcane straw hydrolysate in which glucose concentration was set to $40 \mathrm{gL}^{-1}$ with an addition of $2 \mathrm{gL}^{-1} \mathrm{KH}_{2} \mathrm{PO}_{4}, 2 \mathrm{gL}^{-1} \mathrm{MgSO}_{4} .7 \mathrm{H}_{2} \mathrm{O}$, and $1 \mathrm{gL}^{-1}$ yeast extract. The initial $\mathrm{pH}$ value of the hydrolysate was adjusted to 7.0 . Then, the mixture was sterilized at $121^{\circ} \mathrm{C}$ for $20 \mathrm{~min}$. Later, fungal inoculum $(7 \mathrm{~mL})$ was inoculated in sterile and cooled medium, followed by incubation on a rotary shaker at $200 \mathrm{rpm}$ and temperature of $28^{\circ} \mathrm{C}$ for $114 \mathrm{~h}$.

\subsection{Kinetic Models of Lasiodiplodan Production Using Sugarcan Straw Hydrolysate}

The production of lasiodiplodan by L. theobromae CCT3966 from sugarcane straw hydrolysate was evaluated by conducting a kinetic study on the production process. In this view, the growth of the fungal strain was described by the logistic (autonomous) model as presented previously by Zhang et al [40]. The logistic model for the growth of microbial growth was defined:

$$
\frac{d X}{d t}=\mu X\left(1-\frac{X}{X_{\max }}\right)
$$

where $\mu$ represents the maximum specific growth rate $\left(\mathrm{h}^{-1}\right), \mathrm{X}$ is fungal biomass $\left(\mathrm{gL}^{-1}\right)$, and $X_{\max }$ is the highest fungal biomass concentration $\left(\mathrm{gL}^{-1}\right)$, which was measured at the end of fermentation. The integration of Equation (2) can give the following Equation:

$$
X_{t}=\frac{X_{o} e^{\mu t}}{1.0-\left[\left(\frac{X_{o}}{X_{\max }}\right)\left(1.0-e^{\mu t}\right)\right]}
$$

where $X_{t}$ is the biomass concentration $\left(\mathrm{gL}^{-1}\right)$ at time $t$ and $X_{o}$ indicates the initial biomass concentration $\left(\mathrm{gL}^{-1}\right)$ at $t=0$ when microbial inoculation was carried out. Equation (4) can be derived from Equation (3) as:

$$
\mu \mathrm{t}=\ln \left[\frac{\left(\frac{X_{t}}{X_{\max }}\right)}{1.0-\left(\frac{X_{t}}{X_{\max }}\right)}\right]-\ln \left[\left(\frac{X_{\max }}{X_{o}}\right)-1.0\right]
$$

where the symbol of $\ln$ denotes the natural logarithm. The value of $\mu$ was calculated by plotting $\ln \left[\frac{\left(\frac{X_{t}}{x_{t} \max }\right)}{1.0-\left(\frac{X_{t}}{X_{\max }}\right)}\right]$ against fermentation time $(t)$ so that it provided a linear graph with a slope of $\mu\left(\mathrm{h}^{-1}\right)$.

The Leudeking-Piret kinetic [41] was utilized to describe lasiodiplodan production as shown in Equation (5):

$$
\frac{d P}{d t}=m \frac{d X}{d t}+n X
$$

Equation (5) includes a growth-associated term $\mathrm{m}(d x / d t)$ and a non-growth associated term $n X$. In consideration of the fact that production of lasiodiplodan by L. theobromae CCT3966 is a growth-associated process, the term $n X$ was, therefore, not included for calculations. The integration of Equation (5) forms:

$$
P_{t}=P_{o}+m X_{o}\left[\frac{e^{\mu t}}{1.0-\left[\left(\frac{X_{o}}{X_{\max }}\right)\left(1.0-e^{\mu t}\right)\right]}-1.0\right]
$$


where $P_{t}$ is lasiodiplodan produced at time $t$ and $P_{t}$ is the lasiodiplodan concentration $\left(\mathrm{gL}^{-1}\right)$ at $t=0$. Plotting $P_{t}-P_{o}$ against $X_{o}\left[\frac{e^{\mu t}}{1.0-\left[\left(\frac{X_{0}}{X_{\max }}\right)\left(1.0-e^{\mu t}\right)\right]}-1.0\right]$ generates a linear curve in which the slop is equal to the value of $m$.

The consumption of glucose as a microbial substrate was studied using the kinetic model presented by Zhang et al. [40] as:

$$
S_{t}=S_{o}-\alpha\left(X_{t}-X_{o}\right)-\beta\left(\frac{X_{\max }}{\mu}\right) \ln \left[1.0-\left(\frac{X_{o}}{X_{\max }}\right)\left(1.0-e^{\mu t}\right)\right]
$$

where $S_{t}$ is the substrate (glucose) concentration $\left(\mathrm{gL}^{-1}\right)$ at time $\mathrm{t}$ and the term $S_{o}$ is the initial substrate concentration $\left(\mathrm{gL}^{-1}\right)$ in culture medium at $t=0$. Factors $\alpha$ and $\beta$ denote coefficients. The value of kinetic parameter $\alpha$ was obtained by plotting $S_{o}-S_{t}-$ $\beta\left(\frac{X_{\max }}{\mu}\right) \ln \left[1.0-\left(\frac{X_{o}}{X_{\max }}\right)\left(1.0-e^{\mu t}\right)\right]$ against $\left(X_{t}-X_{\mathbf{o}}\right)$. Therefore, the slope of the linear curve generated denotes value of $\alpha$. The factor $\beta$ was computed by Equation (8):

$$
\beta=\frac{(d S / d t)}{X_{t}}
$$

The statistical evaluation of the proposed models in relation to experimental data was carried out by the mean squared error (MSE) and coefficient of determination $\left(R^{2}\right)[40]$ :

$$
\begin{aligned}
\mathrm{MSE} & =\frac{1}{n} \sum_{i=1}^{n}\left(y_{i}-f_{i}\right)^{2} \\
R^{2} & =1-\frac{\sum\left(y_{i}-f_{i}\right)^{2}}{\sum\left(y_{i}-\bar{y}_{i}\right)^{2}}
\end{aligned}
$$

where $y_{i}, \bar{y}_{i}, f_{i}$, and $n$ represent experimental data, mean of experimental data, the model data, and the number of samples taken for experimental data, respectively. The yield of lasiodiplodan $\left(Y_{p / s}\right)$ was calculated as the ratio of lasiodiplodan produced to the glucose consumed $\left(\mathrm{gg}^{-1}\right)$. The volumetric productivity of lasiodiplodan $\left(Q_{p}\right)$ was measured as the ratio of amount of lasiodiplodan produced to the time of the fermentaion $\left(\mathrm{gL}^{-1} \mathrm{~h}^{-1}\right)$. The ratio of the amount of biomass produced to glucose consumed $\left(\mathrm{gg}^{-1}\right)$ was defined as $Y_{x / s}[1]$.

\subsection{Measurement of Biomass and Lasiodiplodan}

At the end of the lasiodiplodan production process, the culture broth was collected. Fungal biomass was separated by centrifugation at $2860 \times g$ for $10 \mathrm{~min}$. The precipitated biomass was washed properly and dried in an oven at $60{ }^{\circ} \mathrm{C}$ to achieve constant weight. For lasiodiplodan measurement, the supernatant of the culture broth was recovered and the dissolved lasiodiplodan was precipitated by adding $70 \%$ ethanol into fermentation medium with the ratio of 1:3 (1 part mixture and 3 part 70\% ethanol) and the mixture was kept at $4{ }^{\circ} \mathrm{C}$ (overnight). The precipitate was then separated from the supernatant and dried at the temperature of $60{ }^{\circ} \mathrm{C}$ to achieve constant weight. The mass of lasiodiplodan was then weighed using a laboratory balance $[1,16]$.

\subsection{Chemical Characterization of Pretreated Sugarcane Straw}

The chemical content of cellulose, hemicelluloses, and lignin for acid pretreated and alkaline pretreated sugarcane straw was determined using the method presented by National Renewable Energy Laboratory (NREL) [42]. The ash content of sugarcane straw was measured using a muffle furnace at $500^{\circ} \mathrm{C}$ for $24 \mathrm{~h}$.

\subsection{Scanning Electron Microscopy (SEM) of Pretreated Biomass}

In order to study morphological changes in the lignocellulose structure of sugarcane straw after pretreatment, the pretreated biomass was analyzed by SEM (Hitachi TM3000, 
Chiyoda, TYQ, Japan). For this, dilute acid pretreated sugarcane straw and alkaline pretreated sugarcane straw (cellulose pulp) were subjected to SEM for morphological analysis at $1000 \times$ magnification [16].

\subsection{Fourier Transform Infrared (FTIR) Spectroscopy and X-ray Diffraction Analysis (XRD)}

FTIR and XRD analysis of lasiodiplodan samples were performed to study the biochemical structure of lasiodiplodan produced [16]. FT-IR spectrum was recorded in the region of $4000-600 \mathrm{~cm}^{-1}$ using a Perkin Elmer ${ }^{\circledR}$ SpectrumTM GX (Shelton, CT, USA). XRD was conducted over a diffraction angle $(2 \theta)$ of $10-60$. X-ray diffractogram was attained by PANalytical (Malvern Panalytical, UK) [13].

\subsection{Measurement of Glucose in Hydrolysate}

The concentration of sugars was analyzed by High-Performance Liquid Chromatography (HPLC) in a Agilent 1200 series (Agilent Technologies Inc., USA) equipment with a Refractive index detector RID-6A and a HPX-87H $(300 \times 7.8 \mathrm{~mm})$ column (Bio-Rad, USA). The analysis conditions were: column temperature of $45^{\circ} \mathrm{C}$, the solution of $0.01 \mathrm{~N} \mathrm{H}_{2} \mathrm{SO}_{4}$ as the mobile phase, flow rate of $0.6 \mathrm{~mL} / \mathrm{min}$, and $20 \mu \mathrm{L}$ injection volume [13].

\subsection{Statistical Analysis}

Experimental data were statistically analyzed by ordinary one-way ANOVA method and two-way ANOVA followed by Dunnett's multiple comparisons test at 95\% confidence level $(p<0.05)$ using GraphPad Prism 8.0.2 software. The values of kinetic parameters of the models generated were calculated manually.

\section{Results}

\subsection{Chemical Composition of Pretreated Sugarcane Straw}

As discussed earlier, the pretreated sugarcane straw was analyzed for the amount of different components. After nitric acid pretreatment of the raw sugarcane straw, the chemical composition of pretreated sugarcane straw was analyzed. The lignocellulosic contents of acid pretreated sugarcane straw are presented in Table 1. The chemical composition profile of sugarcane straw pretreated with dilute nitric acid revealed that the hemicellulosic content in untreated sugarcane straw reached $3.53 \%$ after acid pretreatment.

Table 1. Chemical composition of sugarcane straw: untreated biomass, after dilute acid $\left(\mathrm{HNO}_{3} 1 \%\right.$ $v / v)$ pretreatment, and after alkaline $(\mathrm{NaOH} 1 \% w / v)$ pretreatment ${ }^{\mathrm{a}}$.

\begin{tabular}{cccc}
\hline Component & Untreated Biomass (\%) $^{\mathbf{c}}$ & $\begin{array}{c}\text { After Acid } \\
\text { Pretreatment (\%) }\end{array}$ & $\begin{array}{c}\text { After Alkaline } \\
\text { Pretreatment (\%) }\end{array}$ \\
\hline Cellulose & $41.25 \pm 1.10$ & $62.28 \pm 1.11$ & $82.22 \pm 1.04$ \\
Hemicelluloses & $35.17 \pm 0.30$ & $3.53 \pm 0.40$ & $\mathrm{ND}^{\mathrm{b}}$ \\
Lignin & $17.25 \pm 3.39$ & $32.15 \pm 0.44$ & $16.28 \pm 1.35$ \\
Ash & $2.81 \pm 1.43$ & $2.265 \pm 0.007$ & $1.73 \pm 0.29$ \\
\hline
\end{tabular}

a Values based on mean \pm standard deviation; ${ }^{\mathrm{b}}$ ND: Not Detected; ${ }^{\mathrm{c}}$ [36].

On the other hand, the amount of cellulose and lignin components of sugarcane straw after acid pretreatment reached $62.28 \%$ and $32.15 \%$, respectively (Table 1 ). It is noteworthy that the acid pretreatment of the lignocellulosic structure of plants causes a considerable hydrolysis of hemicellulosic content. However, cellulose is hydrolyzed by acid to a lesser extent.

As can be observed in Table 1, the sugarcane straw obtained after alkaline pretreatment was composed of $82.22 \%$ cellulose, indicating that cellulose content notably increased compared to the cellulose content recorded after acid pretreatment of sugarcane straw $(62.28 \%)$.

In addition, it was also recorded that the hemicellulose fraction decreased even more and was not detected after alkaline hydrolysis of acid pretreated sugarcane straw. Moreover, the lignin content of alkaline pretreated sugarcane straw decreased to $16.28 \%$, indicating 
the success of alkaline pretreatment in lignin removal (49.36\%) after alkaline pretreatment (Table 1). The statistical analysis of the pretreatment experiments showed that cellulose content of sugarcane straw was significantly enhanced after acid pretreatment compared to raw sugarcane straw $(p<0.01)$ as well as after alkaline pretreatment in comparison to that for raw sugarcane straw and acid pretreated biomass $(p<0.01)$. On the other hand, the hemicellulose content of untreated sugarcane straw significantly decreased in both acid pretreated and alkaline pretreated biomass $(p<0.01)$. Although the lignin content of sugarcane straw significantly decreased after alkaline pretreatment compared to that in acid pretreated biomass $(p<0.01)$, variation in the lignin content of sugarcane straw was not significant after alkaline pretreatment compared to that in untreated biomass $(p>0.05)$.

\subsection{Pretreatment Effect on Structural Modification of Sugarcane Straw}

SEM of the pretreated sugarcane straw was carried out to study the structural modification after acid and alkaline pretreatment. Figure 1 depicts SEM images of pretreated sugarcane straw. As shown in Figure 1A, acid pretreated sugarcane straw revealed disordered fibrous organization with rupture in vascular cells. The changes in morphology of xylem structure are displayed as broken vessel elements and tracheids with the thin and dissociated cell wall. Figure 1B depicts the micrograph of sugarcane straw pretreated by alkaline after acid pretreatment. It can be observed that deep fracture in the fibrous organization with perpendicular breaks in the fiber cells occurred, indicating the increase in the accessibility of the enzymes to the structure of delignified sugarcane straw for hydrolysis of cellulose fraction.

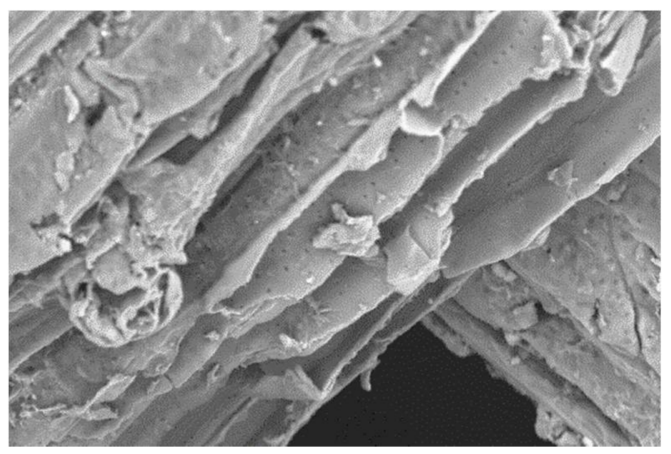

(A)

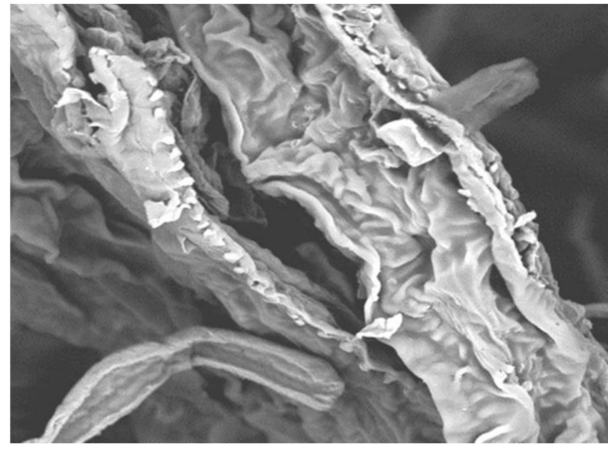

(B)

Figure 1. SEM images of the pretreated sugarcane straw with magnification of $1000 \times$ : (A) $\mathrm{HNO}_{3}$ pretreated sugarcane straw; (B) $\mathrm{NaOH}$ pretreated sugarcane straw following acid pretreatment.

\subsection{Enzymatic Hydrolysis of Raw and Pretreated Sugarcane Straw}

Delignified sugarcane straw obtained after alkaline pretreatment was hydrolyzed by the cellulase preparation. The results of enzymatic saccharification of the pretreated sugarcane straw revealed that the concentration of glucose released at $6,12,24,48$, and $72 \mathrm{~h}$ were $3.25,21.16,42.06,44.21$, and $47.10 \mathrm{gL}^{-1}$, respectively (Figure 2A). The results indicated that a high amount of glucose was released at $24 \mathrm{~h}$ of enzymatic saccharification, while the rise in glucose released from 24 to $72 \mathrm{~h}$ was comparatively not considerable.

Statistical analysis of the glucose produced in enzymatic hydrolysis of delignified sugarcane straw (Figure 2) corroborated that the concentration of glucose was significantly enhanced $(p<0.01)$ during the initial $24 \mathrm{~h}$ of hydrolysis time. The comparison of glucose released after $24 \mathrm{~h}$ of enzymatic saccharification indicated that the increase in glucose concentration was insignificant $(p>0.05)$ between 24 to $72 \mathrm{~h}$ of enzymatic hydrolysis.

In this regard, glucose released could have an inhibitory effect on the cellulase so that increasing glucose concentration during cellulose hydrolysis dwindled enzymatic saccharification. Furthermore, the more accessible cellulose fraction can be hydrolyzed in the first hours of hydrolysis, remaining a more recalcitrant biopolymer in later times. This fact is also shown by the cellulose to glucose conversion yield (Figure 2B). 


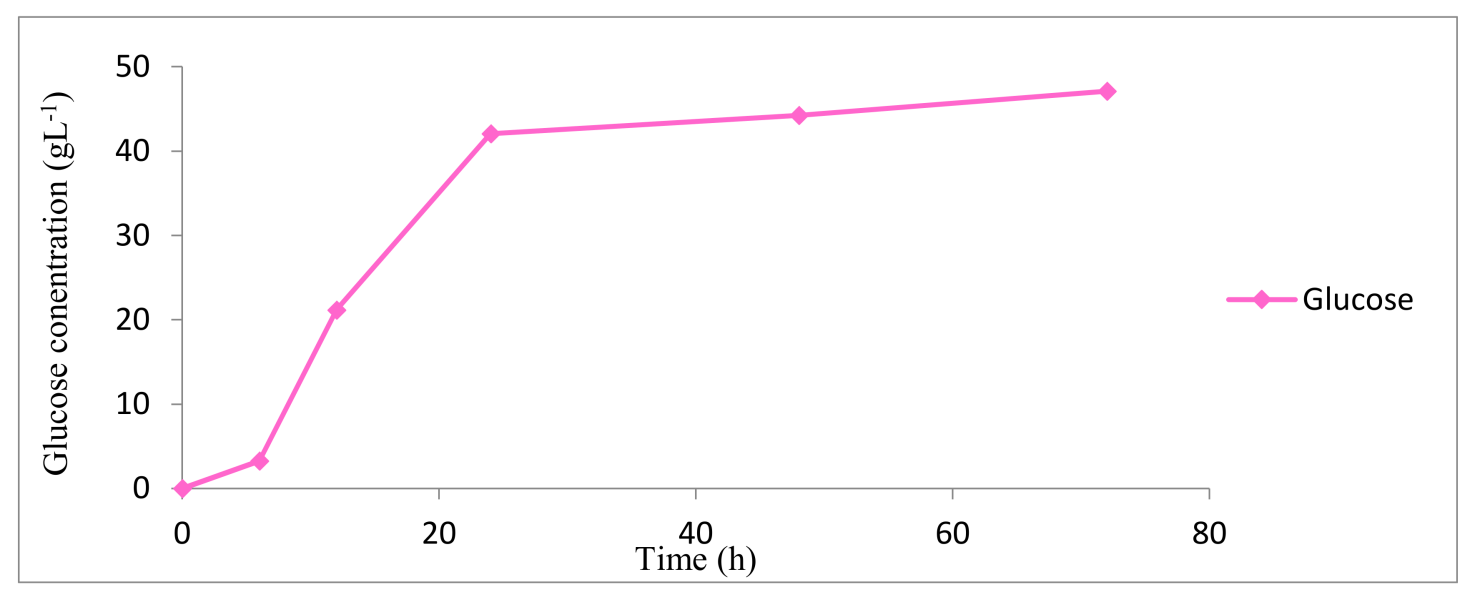

(A)

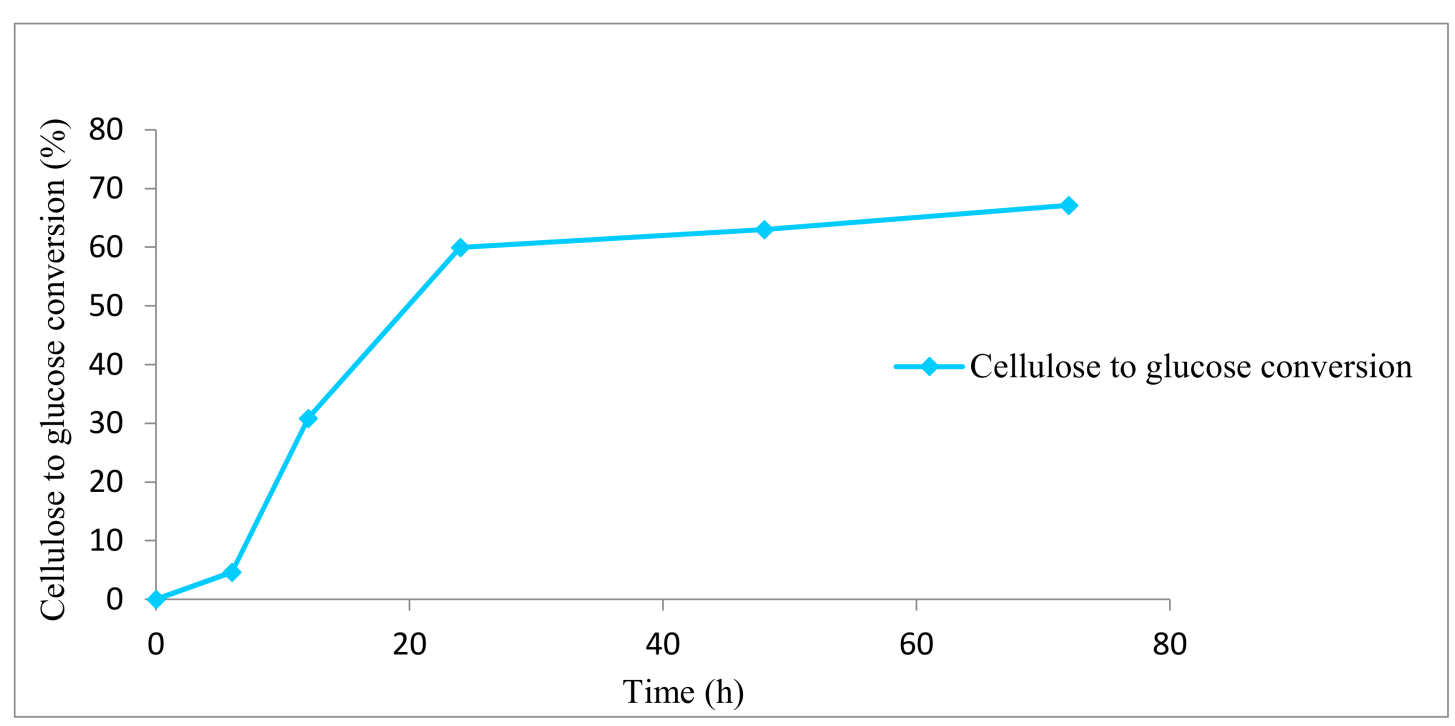

(B)

Figure 2. The profile of enzymatic hydrolysis of pretreated sugarcane straw during $72 \mathrm{~h}$ of hydrolysis time: (A) concentration of glucose released; (B) cellulose to glucose conversion percentage.

As can be found from Figure 2B, the conversion percentage of cellulose to glucose for enzymatic hydrolysis at $6,12,24,48$, and $72 \mathrm{~h}$ was $4.63,30.87,59.98,63.05$, and $67.15 \%$, respectively, indicating an increasing trend in the conversion of cellulose to glucose with period of hydrolysis. It is noteworthy that a high yield of glucose conversion was obtained in the first $24 \mathrm{~h}$ enzymatic hydrolysis. This result showed that glucose conversion reached about $70 \%$ in $72 \mathrm{~h}$ of hydrolysis, but about $60 \%$ of conversion yield was achieved in the first $24 \mathrm{~h}$.

\subsection{Lasiodiplodan Production Using Sugarcane Straw Hydrolysate}

Figure 3A depicts the time course for the growth of L. theobromae CCT3966 in sugarcane straw hydrolysate. As shown, the lag phase was not long. The initial fungal biomass $\left(X_{o}=0.13 \mathrm{gL}^{-1}\right)$ started to grow shortly after the inoculation $(t=0)$. The fungal cells grew drastically during $96 \mathrm{~h}$ of fermentation indicating the exponential phase of the growth. The maximum specific growth rate $(\mu)$ was obtained at exponential growth phase with the value of $0.06 \mathrm{~h}^{-1}$. Similarly, the decrease in biomass growth was recorded after $96 \mathrm{~h}$ of fermentation, with a stationary phase of the biomass growth from $96 \mathrm{~h}$ to $114 \mathrm{~h}$ of fermentation. The highest biomass formed $\left(X_{\max }\right)$ was $3.01 \mathrm{gL}^{-1}$. The growth of the isolate 
L. theobromae CCT3966 in the sugarcane straw hydrolysate was studied by the logistic model. Here, the growth of fungal cells in sugarcane straw hydrolysate followed the growth pattern generated by the model. This indicated that the kinetic model could predict well the growth of the biomass in experimental conditions. The values of the kinetic parameters of the model are shown in Table 2.

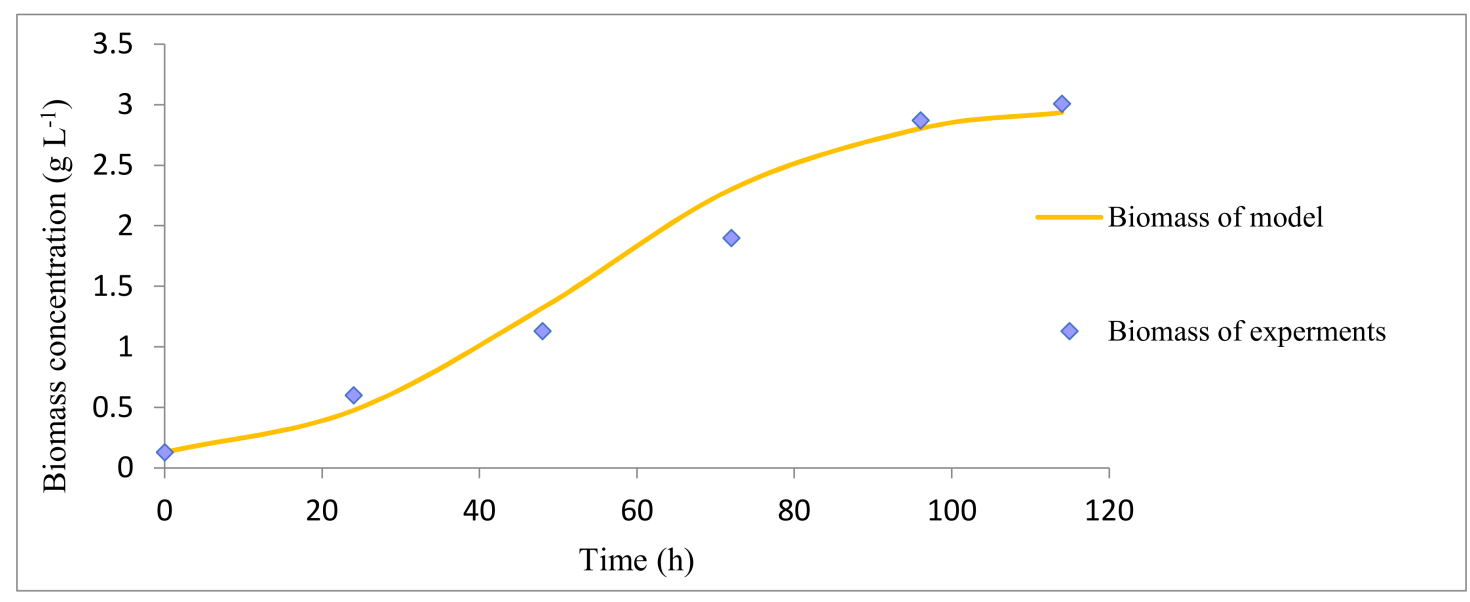

(A)

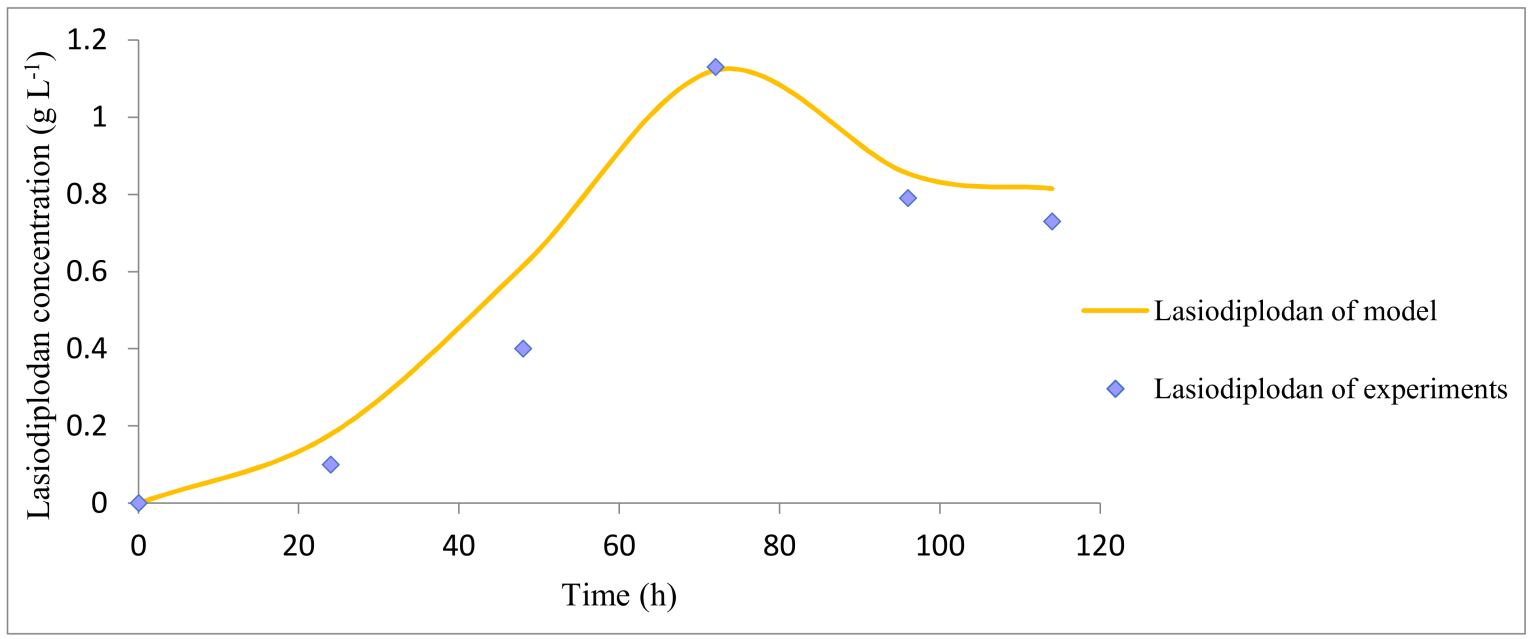

(B)

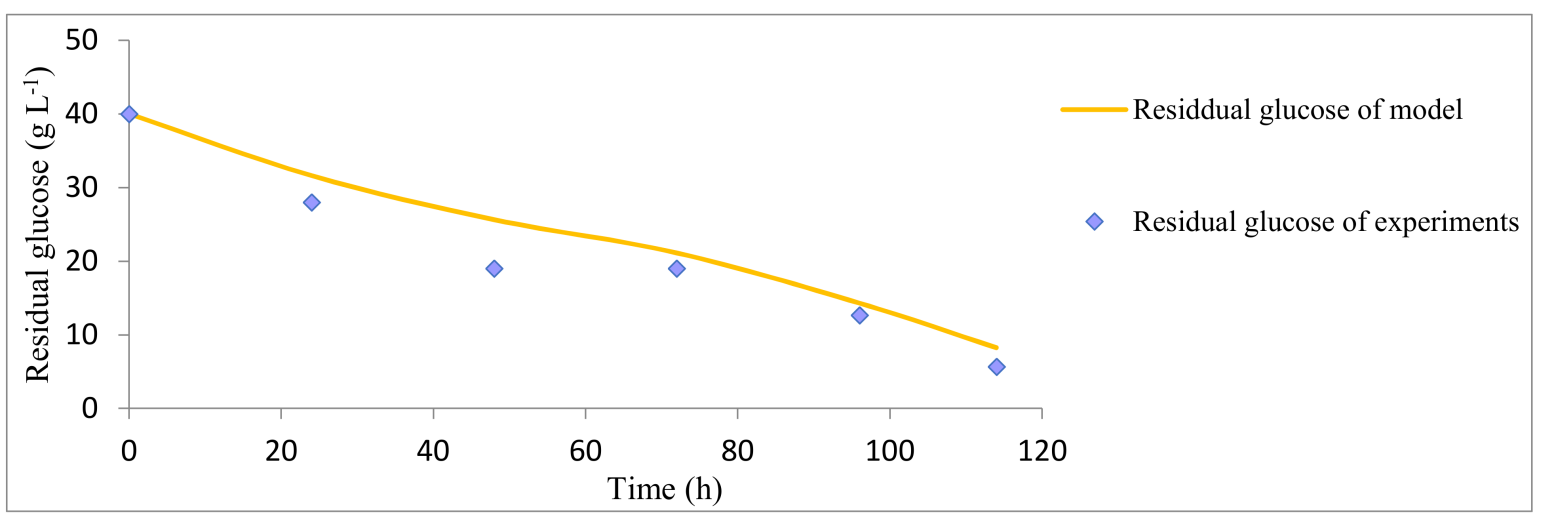

(C)

Figure 3. The profile of time course of fermentation process of L. theobromae CCT3966 in sugarcane straw hydrolysate: (A) the fungal growth, (B) lasiodiplodan production, (C) glucose consumption. 
Table 2. The kinetic parameters for lasiodiplodan production from sugarcane straw hydrolysate in batch fermentation.

\begin{tabular}{cc}
\hline Kinetic Parameter & Value \\
\hline$X_{o}$ & $0.13 \mathrm{gL}^{-1}$ \\
$X_{\max }$ & $3.01 \mathrm{gL}^{-1}$ \\
$\mu$ & $0.06 \mathrm{~h}^{-1}$ \\
$\alpha$ & $4.54 \mathrm{gg}^{-1}$ \\
$Y_{p / s}$ & $0.054 \mathrm{gg}^{-1}$ \\
$Q_{p}$ & $0.016 \mathrm{gL}^{-1} \mathrm{~h}^{-1}$ \\
$Y_{x / s}$ & $0.09 \mathrm{gg}^{-1}$ \\
\hline$X_{0,}$
\end{tabular}

$\overline{X_{0}}$, initial biomass; $X_{\max }$, the highest biomass production; $\mu$, maximum.specific growth rate; $\alpha$, lasiodiplodan production coefficient; $Y_{p / s}$, yield of lasiodiplodan production; $Q_{p}$, volumetric productivity of lasiodiplodan production; $Y_{x / s}$, fungal biomass yield.

The production of lasiodiplodan by L. theobromae CCT3966 is shown in Figure 3B. It shows that the gradual production of lasiodiplodan by the fungal cells was carried out during initial $24 \mathrm{~h}$ of fermentation. However, the production of lasiodiplodan exhibited an increasing trend from 24 to $72 \mathrm{~h}$ of the fermentation. The highest lasiodiplodan yield $\left(Y_{p / x}\right)$ and productivity $\left(Q_{p}\right)$ of $0.054 \mathrm{gg}^{-1}$ glucose consumed and $0.016 \mathrm{gL}^{-1} \mathrm{~h}^{-1}$ were recorded, respectively, at $72 \mathrm{~h}$ of fermentation.

Moreover, it was also observed that the further increase in the fermentation time from 72 to $114 \mathrm{~h}$ had no positive effect on the production of lasiodiplodan. The reduction in lasiodiplodan production after $72 \mathrm{~h}$ was possibly due to the depletion of nutrients (glucose and yeast extract) and dissolved oxygen in the culture medium since these are the decisive factors for fungal growth and lasiodiplodan synthesis. Figure 3A,B clearly indicated that the production of lasiodiplodan by the strain L. theobromae CCT3966 was a growth-associated process since the maximum lasiodiplodan production was obtained in the exponential growth phase.

Figure 3B also depicts the pattern of lasiodiplodan production presented by the kinetic model generated. As shown, the biosynthesis of lasiodiplodan by the strain L. theobromae CCT3966 in experimental fermentation was satisfactorily correlated with lasiodiplodan production presented by the kinetic model.

Figure $3 \mathrm{C}$ depicts the profile of the glucose consumption in the production of lasiodiplodan by the isolate L. theobromae CCT3966. It was observed that fugal cells utilized glucose continuously from the early fermentation course to end. The fungal biomass consumed most of the initial amount of glucose until $72 \mathrm{~h}$ of fermentation time $\left(21.01 \mathrm{gL}^{-1}\right)$ when the highest production of lasiodiplodan occurred (Figure 3A). As fermentation proceeded, a low quantity of glucose $\left(13.32 \mathrm{gL}^{-1}\right)$ was utilized by the fungal cells during $72 \mathrm{~h}$ to $114 \mathrm{~h}$ of the fermentation time. The lower glucose consumption after $72 \mathrm{~h}$ was in line with the reduction of lasiodiplodan production during this fermentation course.

It can also be found from Figure $3 \mathrm{C}$ that the glucose presented in the sugarcane straw hydrolysate was not completely consumed as a residual glucose concentration of $5.67 \mathrm{gL}^{-1}$ was measured at the end of fermentation course. Considering the amount of glucose consumed, the yield of fungal biomass $\left(Y_{x / s}\right)$ was $0.09 \mathrm{gg}^{-1}$. As shown in Figure 3C, the glucose consumption by the fungal cells in experimental fermentation was in a favorable agreement with that in the kinetic model.

The statistical analysis of the generated models using $R^{2}$ and MSE revealed that simulated models with $R^{2}$ value 0.9 and MSE value less than $10 \%$ were in good agreement with the experimental results. Moreover, it indicated that the models adequately represented the real process and they could be utilized to explain the process pattern of lasiodiplodan production by L. theobromae CCT3966 from sugarcane straw hydrolysate in batch fermentation. 


\subsection{Chemical Structure of the Lasiodiplodan Produced by L. theobromae CCT3966}

The FTIR spectra of the lasiodiplodan produced by L. theobromae CCT3966 have been illustrated in Figure 4A. The fingerprint areas between $774-938 \mathrm{~cm}^{-1}$ pointed out the presence of bands of glycosidic linkages with the $\beta$-type structure, which can be found in several microbial glucans. Peaks and bands between 1000 and $1200 \mathrm{~cm}^{-1}$ indicate axial deformations on C-C, C-H and R-C-O-C-R (ether) linkages. The absorption peak shown in the $1072 \mathrm{~cm}^{-1}$ could indicate the symmetrical stretching vibrations of $\mathrm{C}=\mathrm{O}$ bonds showing the characteristic of the pyranose ring present in the monomers of glucans. The bands at $1255 \mathrm{~cm}^{-1}$ of FTIR spectra revealed the C-O-C asymmetric stretching vibrations. The band observed in the region $1406 \mathrm{~cm}^{-1}$ could be attributed to the symmetric deformation of $\mathrm{CH}_{2}$ and $\mathrm{COH}$ groups. In this regard, the absorption peak at $1633 \mathrm{~cm}^{-1}$ shows the $\mathrm{C}=\mathrm{O}$ bond, which represents the presence of the glucose ring. The absorption peak detected at the $2932 \mathrm{~cm}^{-1}$ is related to the $\mathrm{C}-\mathrm{H}$ stretching of the $\mathrm{CH}_{2}$ group. The peak shown in $3411 \mathrm{~cm}^{-1}$ indicates the hydroxyl group $(\mathrm{OH})$ stretching.

(A)

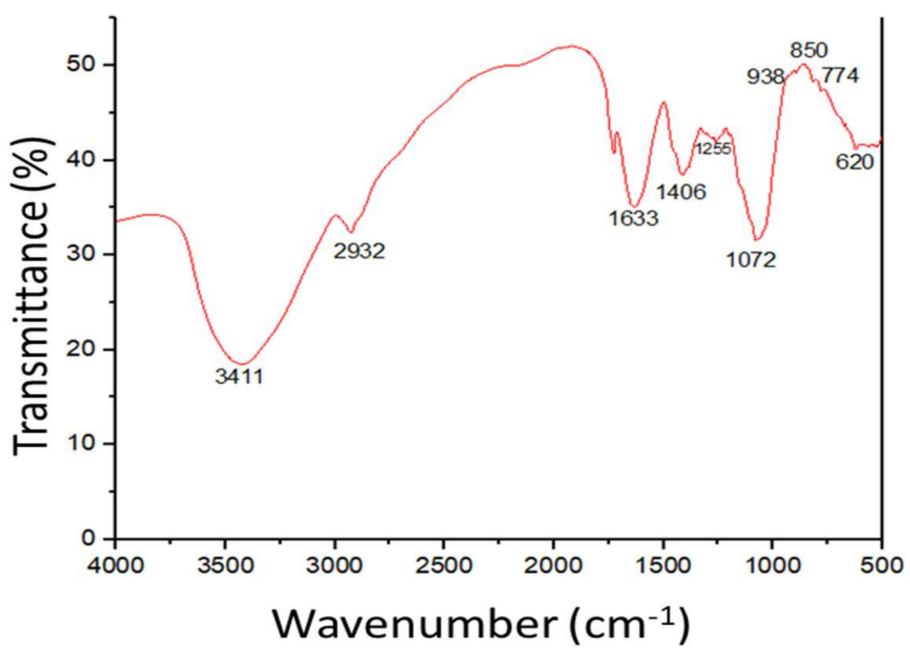

(B)

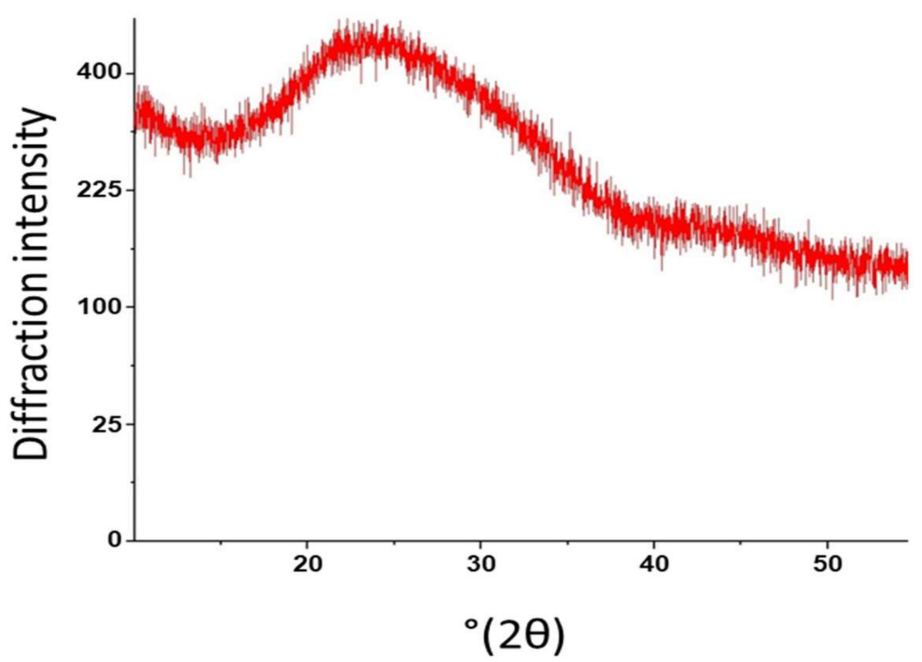

Figure 4. Chemical characterization of lasiodiplodan produced from sugarcane straw hydrolysate by L. theobromae CCT 3966: (A) FT-IR spectra, (B) standard X-ray diffraction profile.

X-ray diffraction of lasiodiplodan produced by L. theobromae CCT3966 is illustrated in Figure $4 \mathrm{~B}$. As can be seen, the diffractogram pattern is shown by a broad peak at around $22^{\circ}(2 \theta)$ indicating the polymeric structure of lasiodiplodan with a non-crystalline property. 


\section{Discussion}

Nitric acid had a notable effect on hemicellulose removal, which could increase cellulose content. In this regard, the study fulfilled by Miléo et al. [32] revealed that the pretreatment of sugarcane straw using $1 \%$ sulfuric acid at $120{ }^{\circ} \mathrm{C}$ for $10 \mathrm{~min}$ resulted in the considerable removal of hemicellulosic fraction from sugarcane straw, from 29.7 to $8.5 \%$. Moutta et al. [43] investigated the pretreatment of sugarcane straw by sulfuric acid $2.9 \%$ $(w / v)$. It was observed that a high amount of hemicellulose composition was hydrolyzed, while cellulose fraction decisively increased.

On the other hand, acid pretreatment could bring about the generation of pseudolignin and the re-condensation of lignin, which leads to the increment of cellulose and lignin content after acid pretreatment compared to that in raw biomass [19,43,44]. After alkaline pretreatment of sugarcane straw, cellulose content increased up to $82.22 \%$. This result is comparable with the results obtained by Candido et al. [25] who applied consecutive acid and alkaline pretreatment for sugarcane straw by sulfuric acid and sodium hydroxide, respectively. They found that the cellulose content of raw sugarcane straw with the value of $38.82 \%$ reached $60.80 \%$ and $84.56 \%$ after acid and subsequent alkaline pretreatment, respectively.

This phenomenon can be attributed to the point that alkaline pretreatment causes the removal of a high quantity of the lignin content, which could enlarge cellulose constitution owing to the swelling of cellulose fibers $[19,45,46]$. The study conducted by Miléo et al. [32] revealed when cellulignin sugarcane straw with hemicellulose and lignin composition of $8.5 \%$ and $38.2 \%$, respectively, was pretreated by $\mathrm{NaOH}(1.5 \% w / v)$, hemicellulose and lignin content decreased to $6.4 \%$ and $26.8 \%$, respectively. It was also observed that the cellulose composition of delignified sugarcane straw reached $57.8 \%$ in comparison to $46.3 \%$ cellulose content of cellulignin sugarcane straw.

After sequential pretreatment of the sugarcane straw using nitric acid and sodium hydroxide, the enzymatic saccharification of pretreated biomass resulted in a remarkable cellulose conversion into glucose $(60 \%)$ with releasing $42.06 \mathrm{gL}^{-1}$ glucose in the first $24 \mathrm{~h}$ of hydrolysis (Figure 2). In contrast, the results indicated that there was no significant difference $(p<0.0 .1)$ in the glucose produced between $24 \mathrm{~h}$ to $72 \mathrm{~h}$ of enzymatic hydrolysis. This finding revealed the important effect of the hydrolysis time in enhancement of glucose release during $24 \mathrm{~h}$ so that the rise in glucose production and saccharification percentage was conducted to a lesser extent at $24 \mathrm{~h}$ to $72 \mathrm{~h}$ of hydrolysis reaction [47].

The results obtained for enzymatic saccharification of pretreated sugarcane straw are comparable with the previous studies. The study fulfilled by Santos-Rocha et al. [39] revealed that enzymatic saccharification of hydrothermally pretreated sugarcane straw by cellulase enzyme led to the release of $38 \mathrm{gL}^{-1}$ glucose so that increasing enzymatic reaction time enhanced glucose concentration up to $48.9 \mathrm{gL}^{-1}$. A similar observation was found by Moutta et al. [43], who hydrolyzed sugarcane straw that had been pretreated previously by sulphuric acid $(2.9 \%, 30 \mathrm{~min})$. Their study showed that after $24 \mathrm{~h}$ of enzymatic hydrolysis by cellulase, an amount of $19 \mathrm{gL}^{-1}$ glucose was triggered, while continuous hydrolysis up to $72 \mathrm{~h}$ resulted in $21 \mathrm{gL}^{-1}$ glucose. Pereira et al. [48] conducted pretreatment of sugarcane straw by dilute sulfuric acid $\left(1.5 \%, 121{ }^{\circ} \mathrm{C}, 30 \mathrm{~min}\right)$, followed by enzymatic hydrolysis for $24 \mathrm{~h}$ using cellulase preparations. It was noted that a quantity of $31 \mathrm{gL}^{-1}$ glucose was produced after $24 \mathrm{~h}$. In an attempt, sugarcane straw was utilized for converting cellulose fraction to glucose by cellulose-degrading enzymes. It was found that enzymatic saccharification of alkaline pretreated sugarcane straw could hydrolyze cellulose to release glucose with an overall cellulose conversion of $67 \%$ [49].

In this study, production of lasiodiplodan occurred from the beginning of the fermentation time and continued to the highest lasiodiplodan production at $72 \mathrm{~h}$ fermentation, while it was followed by a reduced production of lasiodiplodan from 72 to $114 \mathrm{~h}$ showing a correlation between fermentation time and lasiodiplodan formation. This finding indicated that fermentation time is of high importance to attain the highest lasiodiplodan yield when the fungal cells are in the exponential growth phase [9]. 
In this context, the production of lasiodiplodan from glycerol as a carbon source by the fungal strain L. theobromae MMPI in a shake flask revealed that the peak lasiodiplodan was measured at a 72-h time course [9]. A similar pattern was observed by Crognale et al. [50], who found that the highest $\beta$-glucan production by the filamentous fungus Botryosphaeria rhodina DABAC-P82 was obtained at $72 \mathrm{~h}$ fermentation in the shake flask.

The present study showed that the production of lasiodiplodan by the strain L. theobromae CCT3966 was a growth-associated process. Similar findings were reported by Cunha et al. [1] who cultivated the strain L. theobromae MMPI on glucose in a shake flask with triggering the maximum lasiodiplodan production in the exponential growth phase.

Consumption of glucose as a carbon source occurred during the whole fermentation process, while it was not consumed completely. A similar observation was reported by Cunha et al. [1], who cultivated the strain L. theobromae MMPI in a shake flask to produce lasiodiplodan from glucose. They noted that glucose was utilized during the whole 120 -h course of fermentation, and at this stage about $30 \%$ glucose remained in the culture medium.

The study fulfilled by Philippini et al. [13] revealed that the FTIR of glucan polymer lasiodiplodan produced by the strain L. theobromae CCT3966 from corn bran acid hydrolysate showed a $\beta$-type conformation. Similar to the current study, Kagimura et al. [10] showed that the lasiodiplodan produced by L. theobromae MMPI had a structure with a very wide non-crystalline peak in the spectra $20-22^{\circ}(2 \theta)$. In this line, the XRD curve of $\beta$-glucan produced by Saccharomyces cerevisiae exhibited an amorphous phenomenon in which a peak near to $22^{\circ}(2 \theta)$ was observed [51].

\section{Conclusions}

This research showed the feasibility of lasiodiplodan production using the fermentable glucose obtained from sugarcane straw pretreated by $\mathrm{HNO}_{3}(1 \% v / v)$ and $\mathrm{NaOH}(1 \% w / v)$. The statistical analysis of the pretreatment results showed that pretreatments were significantly improved cellulose content and removal of hemicellulose and lignin components of sugarcane straw $(p<0.01)$. Statistical study on the glucose produced in enzymatic hydrolysis of pretreated sugarcane straw revealed that enzymatic hydrolysis contributes to the release of high quantity of glucose during the hydrolysis process $(p<0.01)$. The maximum lasiodiplodan yield and productivity of $0.054 \mathrm{gg}^{-1}$ and $0.016 \mathrm{gL}^{-1} \mathrm{~h}^{-1}$, respectively, were obtained at $72 \mathrm{~h}$ fermentation time. Kinetic study of the fermentation process revealed that the experimental biosynthesis of lasiodiplodan from sugarcane straw hydrolysate followed the trend generated by the kinetic model. The chemical structure of lasiodiplodan produced showed $\beta$-glucan structure. The statistical analysis of the kinetic models using $R^{2}$ value MSE parameters indicated that the experimental results were sufficiently consistent with the simulated models. Sugarcane straw represents a promising substrate for fermentative production of lasiodiplodan and further studies can be conducted for scaling up the production of this biopolymer in the bioreactor.

Author Contributions: Conceptualization, S.S.d.S. and P.A.; methodology, P.A. and J.J.A.; validation, P.A.; formal analysis, P.A.; investigation, P.A.; resources, S.S.d.S. and J.C.d.S.; data curation, P.A.; writing-original draft preparation, P.A.; writing—review and editing, J.J.A., R.R.P., F.A.F.A., A.P.I., M.A. and J.C.d.S.; visualization, P.A.; supervision, S.S.d.S.; project administration, J.C.d.S. and S.S.d.S.; funding acquisition, S.S.d.S. All authors have read and agreed to the published version of the manuscript.

Funding: This work was financially supported by the São Paulo Research Foundation-FAPESP (FAPESP Process No. 2018/14095-7) in São Paulo, Brazil. This work was also supported by Thematic Project of FAPESP (FAPESP Process No. 2016/10636-8).

Institutional Review Board Statement: Not applicable.

Informed Consent Statement: Not applicable. 
Data Availability Statement: The data presented in this study are available on request from the corresponding author. The data are not publicly available due to privacy issue.

Acknowledgments: The authors would like to acknowledge CNPq (Conselho Nacional de Desenvolvimento Científico e Tecnológico), Process No. 303943/2017-3, Brazil. The authors would also like to acknowledge PROFIDES-México for their approved bilateral project. API is highly thankful to SERB, Department of Science and Technology, Government of India for Ramanujan Fellowship (File No. RJF/2019/000044). The authors would also like to acknowledge Fundação André Tosello Pesquisa e Tecnologia (Campinas, SP, Brazil) for providing the strain Lasiodiplodia theobromae CCT3966.

Conflicts of Interest: The authors declare no conflict of interest.

\section{References}

1. Cunha, M.A.A.; Turmina, J.A.; Ivanov, R.C.; Barroso, R.R.; Marques, P.T.; Fonseca, E.A.; Fortes, Z.B.; Dekker, R.F.; Khaper, N.; Barbosa, A.M. Lasiodiplodan, an exocellular (1-6)-b-D-glucan from Lasiodiplodia theobromae MMPI: Production on glucose, fermentation kinetics, rheology and anti-proliferative activity. J. Ind. Microbiol. Biotechnol. 2012, 39, 1179-1188. [CrossRef] [PubMed]

2. Varelas, V.; Tataridis, P.; Liouni, M.; Nerantzis, E.T. Valorization of winery spent yeast waste biomass as a new source for the production of $\beta$-glucan. Waste Biomass Valorization 2016, 7, 807-817. [CrossRef]

3. Abdeshahian, P.; Ascencio, J.J.; Philippini, R.R.; Antunes, F.A.F.; de Carvalho, A.S.; dos Santos, J.C.; da Silva, S.S. Valorization of lignocellulosic biomass and agri-food processing wastes for production of glucan polymer. Waste Biomass Valorization 2021, 12, 2915-2931. [CrossRef]

4. $\quad$ Oliveira, K.S.; Di Bastiani, M.; Cordeiro, L.M.; Costa, M.F.; Toledo, K.A.; Iacomini, M.; Babosa, A.M.; Dekker, R.F.; Nascimento, V.M. $(1 \rightarrow 6)$ - and $(1 \rightarrow 3)(1 \rightarrow 6)-\beta$-glucans from Lasiodiplodia theobromae MMBJ: Structural characterization and pro-inflammatory activity. Carbohydr. Polym. 2015, 20, 539-546. [CrossRef] [PubMed]

5. Cunha, M.A.A.; Santos, V.A.Q.; Calegari, G.C.; Luna, W.N.S.; Marin, S.L.A.; Dekker, R.F.H.; Barbosa-Dekker, A.M. Structure and biological properties of lasiodiplodan: Anuncommon fungal exopolysaccharide of the $(1 \rightarrow 6)-\beta$-D-glucan type. In Extracellular Sugar-Based Biopolymers Matrices; Cohen, E., Merzendorfer, H., Eds.; Springer Nature: Cham, Switzerland, $2019 ;$ pp. $409-432$.

6. Theis, T.V.; Calegari, G.C.; Santos, V.A.Q.; Junior, H.E.Z.; Barbosa, A.M.; Dekker, R.F.H.; Cunha, M.A.A. Exocellular (1 $\rightarrow 6$ )- $\beta$-Dglucan (Lasiodiplodan): Carboxymethylation, thermal behavior, antioxidant and antimicrobial activity. Am. J. Immunol. 2017, 13, 19-33. [CrossRef]

7. Ferreira, R.G.; Azzoni, A.R.; Freitas, S. Review on the production cost of lignocellulose-degrading enzymes. Biofuel Bioprod. Biorefin. 2021, 15, 85-99. [CrossRef]

8. Kagimura, F.Y.; Cunha, M.A.A.; Theis, T.V.; Barbosa, A.M.; Teixeira, S.D.; Dekker, R.F.H. Production of the exopolysaccharide lasiodiplodan in a stirred-tank bioreactor. Synerg. Scyentífica UTFPR 2015, 10, 1-8.

9. Tabuchi, S.C.T.; Martiniano, S.E.; Cunha, M.A.A.; Barbosa-Dekke, A.M.; Dekker, R.F.H.; Prata, A.M.R. Kinetic Study of Lasiodiplodan Production by Lasiodiplodia theobromae MMPI in a Low-Shear Aerated and Agitated Bioreactor. J. Polym. Environ. 2021, 29, 89-102. [CrossRef]

10. Kagimura, F.Y.; Cunha, M.A.A.; Theis, T.V.; Malfatti, C.R.M.; Dekker, R.F.H.; Barbosa, A.M.; Teixeira, S.D.; Salomé, K. Carboxymethylation of $(1 \rightarrow 6)$ - $\beta$-glucan (lasiodiplodan): Preparation, characterization and antioxidant evaluation. Carbohydr. Polym. 2015, 127, 390-399. [CrossRef] [PubMed]

11. Pflügl, S.; Marx, H.; Mattanovich, D.; Sauer, M. Heading for an economic industrial upgrading of crude glycerol from biodiesel production to 1,3-propanediol by Lactobacillus diolivorans. Bioresour. Technol. 2014, 152, 499-504. [CrossRef] [PubMed]

12. Li, Y.; Zhu, S.; Ge, X. Co-production of 1,3-propanediol and 2,3-butanediol from waste lard by co-cultivation of Pseudomonas alcaligenes and Klebsiella pneumonia. Curr. Microbiol. 2019, 76, 415-424. [CrossRef]

13. Philippini, R.R.; Martiniano, S.E.; Marcelino, P.R.F.; Chandel, A.K.; dos Santos, J.C.; da Silva, S.S. Production of $\beta$-glucan exopolysaccharide lasiodiplodan by Lasiodiplodia theobromae CCT3966 from corn bran acid hydrolysate. Appl. Microbiol. Biotechnol. 2021, 105, 2319-2332. [CrossRef] [PubMed]

14. Cho, E.J.; Trinh, L.T.P.; Song, Y.; Lee, Y.G.; Bae, Y.-J. Bioconversion of biomass waste into high value chemicals. Bioresour. Technol. 2020, 298, 122386. [CrossRef] [PubMed]

15. Sarsaiya, S.; Jaina, A.; Awasthic, S.K.; Duanc, Y.; Awasthic, M.K.; Shia, J. Microbial dynamics for lignocellulosic waste bioconversion and its importance with modern circular economy, challenges and future perspectives. Bioresour. Technol. 2019, $291,121905$. [CrossRef] [PubMed]

16. Ascencio, J.J.; Philippini, R.R.; Gomes, F.M.; Pereira, F.M.; da Silva, S.S.; Kumar, V.; Chandel, A.K. Comparative highly efficient production of $\beta$-glucan by Lasiodiplodia theobromae CCT3966 and its multiscale characterization. Fermentation 2021, 7, 108. [CrossRef]

17. Hernández-Pérez, A.F.; de Arruda, P.V.; Felipe, M.G.A. Sugarcane straw as a feedstock for xylitol production by Candida guilliermondii FTI 20037. Braz. J. Microbiol. 2016, 47, 489-496. [CrossRef] [PubMed]

18. de Aquino, G.S.; de Conti Medina, C.; da Costa, D.C.; Shahab, M.; Santiago, A.D. Sugarcane straw management and its impact on production and development of rations. Ind. Crops Prod. 2017, 102, 58-64. [CrossRef] 
19. Carvalho, D.M.; Sevastyanova, O.; Penna, L.S.; Silva, B.P.; Lindstromb, M.E.; Colodette, J.L. Assessment of chemical transformations in eucalyptus, sugarcane bagasse and straw during hydrothermal, dilute acid, and alkaline pretreatments. Ind. Crops Prod. 2015, 73, 118-126. [CrossRef]

20. Production of Sugar Cane in Brazil from Crop Year 2010/11 to 2020/21. Statista. Available online: https://www.statista.com/ statistics/742530/sugar-cane-production-volume-brazil/ (accessed on 15 June 2021).

21. Menandro, L.M.S.; Cantarella, H.; Franco, H.C.J.; Kölln, O.T.; Pimenta, M.T.B.; Sanches, G.M.; Rabelo, S.C.; Carvalho, J.L.N. Comprehensive assessment of sugarcane straw: Implications for biomass and bioenergy production. Biofuel Bioprod. Biorefin. 2017, 11, 488-504. [CrossRef]

22. Moutta, R.O.; Silva, M.C.; Corrales, R.C.N.R.; Cerullo, M.A.S.; Ferreira-Leitão, V.S.; Bon, E.P.S. Comparative response and structural characterization of sugarcane bagasse, straw and bagasse-straw 1:1 mixtures subjected to hydrothermal pretreatment and enzymatic conversion. J. Microb. Biochem. Technol. 2013, 12, 1-8.

23. Gómez, E.O.; Souza, R.T.G.; Rocha, G.J.M.; Almeida, E.; Cortez, L.A.B. Sugarcane trash as feedstock for second generation processes. In Sugarcane Bioethanol—RED for Productivity and Sustainability; Cortez, L.A.B., Ed.; Blucher: São Paulo, Brazil, 2014; pp. 637-660.

24. Lachos-Perez, D.; Tompsett, G.A.; Guerra, P.; Timko, M.T.; Rostagno, M.A.; Martínez, J.; Forster-Carneiro, T. Sugars and char formation on subcritical water hydrolysis of sugarcane straw. Bioresour. Technol. 2017, 243, 1069-1077. [CrossRef] [PubMed]

25. Candido, R.G.; Mori, N.R.; Gonçalves, A.R. Sugarcane straw as feedstock for 2G ethanol: Evaluation of pretreatments and enzymatic hydrolysis. Ind. Crops Prod. 2019, 142, 111845. [CrossRef]

26. Chukwuma, O.B.; Rafatullah, M.; Tajarudin, H.A.; Ismail, N. Lignocellulolytic enzymes in biotechnological and industrial processes: A review. Sustainability 2020, 12, 7282. [CrossRef]

27. Ferdeș, M.; Dincă, M.N.; Moiceanu, G.; Zăbavă, B.S.; Paraschiv, G. Microorganisms and enzymes used in the biological pretreatment of the substrate to enhance biogas production: A review. Sustainability 2020, 12, 7205. [CrossRef]

28. Chaudhary, N.; Qazi, J.I.; Irfan, M. Isolation and identification of cellulolytic and ethanologenic bacteria from soil. Iran. J. Sci. Technol. Trans. Sci. 2017, 41, 551-555. [CrossRef]

29. Mulyaningtyas, A.; Sediawan, W.B. Effect of combined pretreatment of lignocellulose and the kinetics of its subsequent bioconversion by Aspergillus niger. Biocatal. Agric. Biotechnol. 2019, 21, 101292. [CrossRef]

30. Kang, Q.; Appels, L.; Tan, T.; Dewil, R. Bioethanol from lignocellulosic biomass: Current findings determine research priorities. Sci. World J. 2014, 1-13. [CrossRef]

31. Zaafouri, K.; Ziadi, M.; Trabelsi, A.B.H.; Mekni, S.; Aïssi, B.; Alaya, M.; Bergaoui, L.; Hamdi, M. Optimization of hydrothermal and diluted acid pretreatments of Tunisian Luffa cylindrica (L.) fibers for $2 \mathrm{G}$ bioethanol production through the cubic central composite experimental design CCD: Response surface methodology. BioMed. Res. Int. 2017, 2017, 1-14. [CrossRef] [PubMed]

32. Miléo, P.C.; Rodrigues, L.C.; Gandara, M.; Rocha, G.J.M.; Goncalves, A.R. Cellulose. In biorefinary: Fibres obtainment form sugarcane bagasse and pretreated by diluted acid and delignified by alkali. In Proceedings of the 20th European Biomass Conference and Exhibition, Milan, Italy, 18-22 June 2012.

33. De Jong, E.; Gosselink, R.J.A. lignocellulose-based chemical products. In Bioenergy Research: Advances and Applications; Gupta, V.K., Tuohy, M.G., Kubicek, C.P., Saddler, J., Xu, F., Eds.; Elsevier: Amsterdam, The Netherlands, 2014; pp. $277-313$.

34. Jia, Z.; Zheng, Y.; Zhou, J. Effects of different pretreatment methods on the enzymatic hydrolysis of cassava residue. BioResources 2019, 14, 6060-6078. [CrossRef]

35. Dzieko'nska-Kubczak, U.; Berłowska, J.; Dziugan, P.; Patelski, P.; Pielech-Przybylska, K.; Balcerek, M. Nitric acid pretreatment of jerusalem artichoke stalks for enzymatic saccharification and bioethanol production. Energies 2018, 11, 2153. [CrossRef]

36. Abdeshahian, P.; Ascencio, J.J.; Philippini, R.R.; Antunes, F.A.F.; dos Santos, J.C.; da Silva, S.S. Utilization of sugarcane straw for production of $\beta$-glucan biopolymer by Lasiodiplodia theobromae CCT3966 in batch fermentation process. Bioresour. Technol. 2020, 314, 123716. [CrossRef] [PubMed]

37. Kusmiyati, K.; Anarki, S.T.; Nugroho, S.W.; Widiastutik, R.; Hadiyanto, H. Effects of dilute acid and alkaline pretreatments on enzymatic saccharification of palm tree trunk waste for bioethanol produc-tion. Bull. Chem. React. Eng. Catal. 2019, 14, 705-714. [CrossRef]

38. Tri, C.L.; Khuong, L.D.; Kamei, I. The improvement of sodium hydroxide pretreatment in bioethanol production from Japanese bamboo Phyllostachys edulis using the white rot fungus Phlebia sp. MG-60. Int. Biodeterior. Biodegradation 2018, 133, 86-92. [CrossRef]

39. Santos-Rocha, M.S.R.; Pratto, B.; Corrêa, L.J.; Badino, A.C.; Almeida, R.M.R.G.; Cruz, A.J.G. Assessment of different biomass feeding strategies for improving the enzymatic hydrolysis of sugarcane straw. Ind. Crops Prod. 2018, 125, 293-302. [CrossRef]

40. Zhang, Q.; Sun, J.; Wang, Z.; Hang, H.; Zhao, W.; Zhuang, Y.; Chu, J. Kinetic analysis of curdlan production by Alcaligenes faecalis with maltose, sucrose, glucose and fructose as carbon sources. Bioresour. Technol. 2018, 259, 319-324. [CrossRef] [PubMed]

41. Luedeking, R.; Piret, E.L. A kinetic study of the lactic acid fermentation. Batch process at controlled pH. Biotechnol. Bioeng. 2000, 67, 636-644. [CrossRef]

42. Sluiter, A.; Hames, B.; Ruiz, R.; Scarlata, C.; Sluiter, J.; Templeton, D.; Crocker, D. Determination of Structural Carbohydrates and Lignin in Biomass; National Renewable Energy Laboratory: Golden, CO, USA, 2011.

43. Moutta, R.O.; Ferreira-Leitao, V.S.; Bon, E.P.S. Enzymatic hydrolysis of sugarcane bagasse and straw mixtures pretreated with diluted acid. Biocatal. Biotransformation 2014, 32, 93-100. [CrossRef] 
44. Cortez, D.V.; Roberto, I.C.; Barbosa, M.H.P.; Milagres, A.M.F. Evaluation of cellulosic and hemicellulosic hydrolysate fermentability from sugarcane bagasse hyborids with different compositions. Biomass Convers. Biorefin. 2014, 4, 351-356. [CrossRef]

45. Guilherme, A.A.; Dantas, P.V.F.; Soares, J.C.J.; Santos, E.S.; Fernandes, F.A.N.; Macedo, G.R. Pretreatments and enzymatic hydrolysis of sugarcane bagasse aiming at the enhancement of the yield of glucose and xylose. Braz. J. Chem. Eng. 2017, 34, 937-947. [CrossRef]

46. Rocha, M.S.R.S.; Pratto, B.; Júnior, R.S.; Almeida, R.M.R.G.; Cruz, A.J.G. A kinetic model for hydrothermal pretreatment of sugarcane straw. Bioresour. Technol. 2017, 228, 176-185. [CrossRef]

47. Alrumman, S.A. Enzymatic saccharification and fermentation of cellulosic date palm wastes to glucose and lactic acid. Braz. J. Microbiol. 2016, 47, 110-119. [CrossRef] [PubMed]

48. Pereira, S.C.; Maehara, L.; Machado, C.M.M.; Farinas, C.S. 2G ethanol from the whole sugarcane lignocellulosic biomass. Biotechnol. Biofuels 2015, 8, 44. [CrossRef] [PubMed]

49. Oliveira, L.R.M.; Nascimento, V.M.; Goncalves, A.R.; Rocha, G.J.M. Combined process system for the production of bioethanol fromsugarcane straw. Ind. Crops Prod. 2014, 58, 1-7. [CrossRef]

50. Crognale, S.; Federici, F.; Petruccioli, M. $\beta$-Glucan production by Botryosphaeria rhodina on undiluted olive-mill wastewaters. Biotechnol. Lett. 2003, 25, 2013-2015. [CrossRef] [PubMed]

51. Novak, M.; Synytsya, A.; Gedeon, O.; Slepička, P.; Prochazka, V.; Synytsya, A.; Blahovec, J.; Hejlova, A.; Čopikova, J. Yeast $\beta$ (1-3), (1-6)-D-glucan films: Preparation and characterization of some structural and physical properties. Carbohydr. Polym. 2012, 87, 2496-2504. [CrossRef] 